\title{
Review
}

\section{Mistletoe Preparation Iscador: Are there Methodological Concerns with Respect to Controlled Clinical Trials?*}

\section{Renatus Ziegler}

Institut Hiscia, Verein für Krebsforschung, Arlesheim, Switzerland

\begin{abstract}
In Europe many cancer patients use complementary therapies, particularly mistletoe. Only a few controlled clinical trials have been performed with the mistletoe preparation Iscador as a complementary treatment for cancer, many of them with medium to low quality due to methodological shortcomings. Reasons for some quality concerns, particularly discontinuation of treatment and/or participation and premature termination are analyzed. Analysis is based on controlled clinical trials dealing with Iscador. Data stem from the archive of published and ongoing research of the "Verein für Krebsforschung» (Society for Cancer Research) in Arlesheim, Switzerland. Controlled clinical studies with cancer patients that were started after 01.01.1990 or were not completed by then have been evaluated. Fifty-six controlled studies are documented, 24 of them randomized and 32 non-randomized. Nine of the randomized studies were done by matched-pair design, the others by conventional parallel group design; six of the last were terminated prematurely primarily for slow recruitment due to patient preferences and compliance of physicians. Patient and physician preference seem to be important factors limiting recruitment for randomized trials and hence implementation. This adds to the overall unwillingness of participation by patients with serious diseases. A well-balanced mix of designs using different research methods and outcomes is suggested combined with analyses, in countries where mistletoe therapy in general or Iscador in particular is unknown or not available.
\end{abstract}

Keywords: cancer-patient recruitment-preference

\section{Background}

In Europe, a substantial portion of patients suffering from cancer use complementary therapies. However, evidence of these treatments regarding efficacy on disease progression and survival is discussed controversially (1). Amongst complementary therapies against cancer, aqueous extracts of European mistletoe (Viscum album L.), developed on the basis of anthroposophical medicine, are the most frequently used medications,

For reprints and all correspondence: Dr Renatus Ziegler, Verein für Krebsforschung, Institut Hiscia, Kirschweg 9, CH-4144 Arlesheim, Switzerland; Tel: +4161706 72 45; Fax: +41 6170672 00;

E-mail: ziegler@hiscia.ch

*Expanded and updated version of a lecture given at the International Workshop on Study Methods in Complementary Medicine,

Robert Bosch Stiftung, Stuttgart, April 20-21, 2006. particularly in German speaking countries (2,3). In recent systematic reviews (4-6) the authors concluded that in spite of the longstanding and widespread use of mistletoe preparations, only few controlled clinical trials have been performed; the quality of many older studies is generally medium to low due to methodological shortcomings, the more recent ones tend to be better.

\section{Objective}

Reasons for some specific quality issues, particularly discontinuation of treatment and/or participation and premature termination of recent controlled clinical studies with cancer patients using the mistletoe preparation Iscador as a complementary treatment are analyzed. Consequences for future research are suggested. 


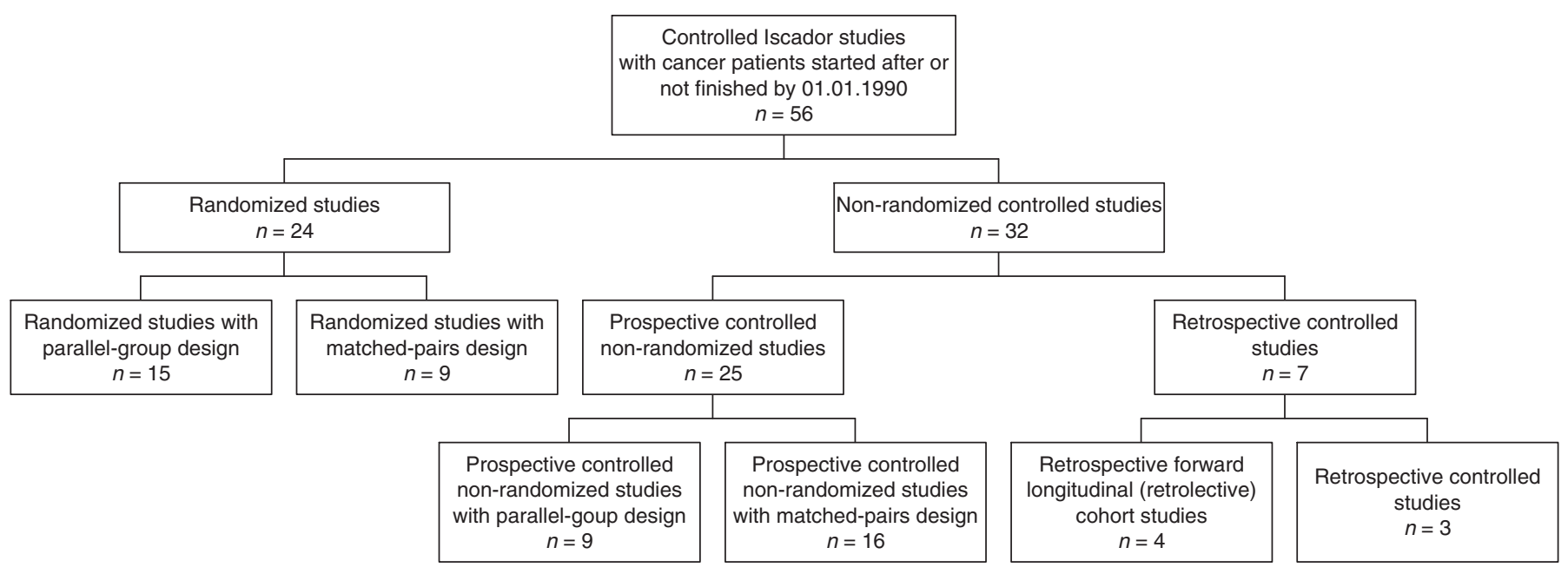

Figure 1. Controlled clinical studies for cancer patients with the mistletoe preparation Iscador; started after or not finished by 01.01 .1990 .

\section{Patients and Methods}

Unfulfilled quality criteria in published research reveal some of the difficulties that mistletoe might encounter but are in some cases not specific for mistletoe. However, looking for concerns intrinsic to research with the mistletoe preparation Iscador, additional information can be gained from difficulties with ongoing research and from reasons for discontinuation. The following analysis is based on controlled clinical studies dealing with the mistletoe preparation Iscador (see subsequently). All data stem from the archive of published and ongoing research of the «Verein für Krebsforschung» (Society for Cancer Research) in Arlesheim, Switzerland. In order to concentrate the analysis on newer research, only controlled clinical studies with cancer patients that were started after 01.01 .1990 or were not completed by then have been evaluated, including non-finished and nonpublished ones $(7,8)$. The control group always received conventional cancer therapy (adjuvant or palliative) and the treatment group additionally Iscador. Within this time frame, 56 controlled studies are documented, 24 of them randomized and 32 non-randomized (Figure 1). Subgroups of these will be discussed separately.

For the discussion of research with other mistletoe products than Iscador and concerning other quality issues, see e.g. $(3,4,6,9)$. References also give a detailed quality assessment of controlled clinical studies with mistletoe preparations $(4,6,9)$.

\section{Mistletoe Characteristics}

Mistletoe extracts for cancer therapy were first used in 1918 by Ita Wegman on the basis of anthroposophy (10). Pharmacological and toxicological properties of mistletoe extracts are documented by various publications on immunological and anti-cancer effects in vitro and in vivo [overviews in $(3,11-14)]$. Iscador is a fermented aqueous extract of European mistletoe (Viscum album L.) that is treated by a special mechanical process of anthroposophical pharmaceutics to increase efficacy (15). There are different doses and sorts of Iscador depending on the host tree, and various application schemes $(12,16)$. Iscador is generally administered subcutaneously two to three times a week. For information concerning the specific therapy regimes, one has to consult the original studies.

Systemic adverse reactions are very rare $(3,17-20)$ and mild to moderate in almost all cases (i.e. CTC/WHO grade 1-2) with spontaneous recovery within one week $(21,22)$. No irreversible events or deaths were reported. This means that there exists no real risk in using mistletoe, which is an important condition for planning and implementing mistletoe studies even if the clinical effects are still discussed controversially (1). However, local reactions at the injection site are frequent with spontaneous recovery after some hours or days. These effects are expected and typical for mistletoe preparations, especially Iscador: in consequence, the dose is adjusted according to the size of the local reaction. This makes it difficult to design a pharmacologically and medically inert placebo showing similar reactions (23). Given this situation, blinding of patients and physicians is nearly impossible. In case a placebo with a similar set of reactions is used, the placebo might not be a true placebo (showing no specific effects) any more and thus results of the treatment comparison might be at least questionable.

\section{Randomized Iscador Studies with Parallel- group Design}

From 15 randomized Iscador studies with parallel-group design (Table 1) six had to be terminated prematurely (No. 3, 4, 6-9). In five cases (No. 3, 6-9) the most important reason was slow recruitment, due to 
Table 1. Randomized mistletoe studies with Iscador in parallel-group design

\begin{tabular}{|c|c|c|c|c|c|}
\hline $\begin{array}{l}\text { Study } \\
\text { No. }\end{array}$ & Indication & Outcome parameter & $\begin{array}{l}\text { Patients } \\
\text { (planned) }\end{array}$ & Status & Reasons for termination \\
\hline 1 & $\begin{array}{l}\text { Non-small-cell } \\
\text { lung cancer }\end{array}$ & Overall survival & 86 Iscador/97 control & $\begin{array}{l}\text { Start 1981, published } \\
1991 \text { (34) }\end{array}$ & - \\
\hline 2 & Melanoma & $\begin{array}{l}\text { Disease-free-interval, } \\
\text { overall survival }\end{array}$ & $2 \times 102$ & $\begin{array}{l}\text { Start 1988, published } \\
\quad 2004(35)\end{array}$ & - \\
\hline 3 & Advanced cancer & QoL (QLQ-C30, SELT, HADS) & $(3 \times 40)$ & Start 1995, terminated 1998 & $\begin{array}{l}\text { Slow recruitment (patient preferences, } \\
\text { language barriers, logistical problems, } \\
\text { refusal of participation in trial), } \\
\text { drop-outs because of death (36) }\end{array}$ \\
\hline 4 & Colon cancer, stage III & $\begin{array}{l}\text { Disease-free survival, } \\
\text { global QoL }\end{array}$ & $(3 \times 150)$ & Start 1996, terminated 1996 & $\begin{array}{l}\text { After study start: negative expert opinion } \\
\text { from DKG (Deutsche Krebsgesellschaft) } \\
\text { concerning insufficient data for mistletoe } \\
\text { which lead to termination }\end{array}$ \\
\hline 5 & Breast cancer & QoL (Spitzer) & 20 Iscador/10 control & $\begin{array}{l}\text { Start 1997, published } \\
\quad 1999 \text { (37) }\end{array}$ & - \\
\hline 6 & $\begin{array}{l}\text { Throat, nose and } \\
\text { ear cancer }\end{array}$ & $\begin{array}{l}\text { Side effects of radiation } \\
\text { therapy (immune } \\
\text { system, DNA, infections) }\end{array}$ & $(2 \times 20)$ & Start 1997, terminated 1999 & $\begin{array}{l}\text { Slow recruitment (suboptimal motivation } \\
\text { and compliance of physicians, } \\
\text { compliance of patients) }\end{array}$ \\
\hline 7 & Breast cancer & $\begin{array}{l}\text { Immunological side } \\
\text { effects of radiation } \\
\text { therapy after operation, QoL }\end{array}$ & $(2 \times 60)$ & Start 1997, terminated 2005 & $\begin{array}{l}\text { Slow recruitment (patient preferences, } \\
\text { refusal), many drop-outs (compliance/motivation } \\
\text { of physicians), shut down of radiation department }\end{array}$ \\
\hline 8 & Bladder cancer & $\begin{array}{l}\text { Safety of pre-operative } \\
\text { Iscador instillation, } \\
\text { anti-tumor effects, QoL }\end{array}$ & $(2 \times 13)$ & Start 1999, terminated 2003 & $\begin{array}{l}\text { Slow recruitment (patient preferences, refusal), } \\
\text { suboptimal motivation and compliance } \\
\text { of physicians }\end{array}$ \\
\hline 9 & Small-cell lung cancer & $\begin{array}{l}\text { QoL (QLQ-C30), } \\
\text { disease-free interval, } \\
\text { overall survival }\end{array}$ & $(2 \times 47)$ & Start 2000, terminated 2001 & very slow recruitment \\
\hline 10 & Colorectal cancer & $\begin{array}{l}\text { Natural killer cell activity during } \\
\text { peri-operative Iscador infusion }\end{array}$ & $2 \times 21$ & $\begin{array}{l}\text { Recruitment 2002-2004, } \\
\text { published } 2007 \text { (38) }\end{array}$ & - \\
\hline 11 & $\begin{array}{l}\text { Non-small-cell } \\
\text { lung cancer }\end{array}$ & $\begin{array}{l}\text { Overall survival, } \\
\text { progression-free interval, } \\
\text { QoL (QLQ-C30), immunological } \\
\text { parameters, safety }\end{array}$ & $(2 \times 25)$ & Recruitment 2004-2007 & - \\
\hline 12 & Breast cancer & $\begin{array}{l}\text { QoL, cortisol level, immunological } \\
\text { parameters }\end{array}$ & $2 \times 24$ & $\begin{array}{l}\text { Recruitment 2005-2006, } \\
\text { published 2004/5 }(39,40)\end{array}$ & - \\
\hline 13 & Breast cancer & $\begin{array}{l}\text { QoL (QLQ-C30), fatigue, neutropenia, } \\
\text { immunological parameters }\end{array}$ & $(3 \times 30)$ & Recruitment 2005-2006 & - \\
\hline 14 & $\begin{array}{l}\text { Colon cancer with } \\
\text { metastases }\end{array}$ & $\begin{array}{l}\text { QoL (QLQ-C30), ECOG, tolerability, } \\
\text { overall survival }\end{array}$ & $(2 \times 25)$ & Start 2005 & - \\
\hline 15 & $\begin{array}{l}\text { Spindle-cell } \\
\text { bone-sarcoma }\end{array}$ & $\begin{array}{l}\text { Post-relapse disease-free } \\
\text { survival, QoL (QLQ-C30) }\end{array}$ & $(2 \times 18)$ & Start 2007 & - \\
\hline
\end{tabular}


Table 2. Example: recruitment and randomization in mistletoe studies (39)

\begin{tabular}{|c|c|c|c|}
\hline$N$ & Characteristics & Exclusion & Reasons for exclusion \\
\hline 1922 & $\begin{array}{l}\text { Breast operation from May } 1999 \text { to August } 2001 \\
\text { in Heidelberg university hospital }\end{array}$ & 518 & Only biopsy, benign tumor \\
\hline 1404 & Diagnosis breast cancer & 883 & $\begin{array}{l}\text { Inclusion criteria not fulfilled or exclusion criteria fulfilled: } \\
\text { no primary breast cancer (316), other stage (105), pre-operative } \\
\text { chemotherapy ( } 72) \text {, age }(63) \text {, other missing inclusion criteria }(73) \text {, } \\
\text { other exclusion criteria (254) }\end{array}$ \\
\hline 521 & $\begin{array}{l}\text { Post-operative check of inclusion and exclusion } \\
\text { criteria with clinical registry }\end{array}$ & 367 & $\begin{array}{l}\text { Refusal of trial in general (184), logistics (74), mistletoe preferred (51), } \\
\text { no histology (42), participation in other study (13), refusal } \\
\text { of chemotherapy (3) }\end{array}$ \\
\hline 154 & $\begin{array}{l}\text { Patient interview: all inclusion and } \\
\text { exclusion criteria OK }\end{array}$ & 80 & $\begin{array}{l}\text { No chemotherapy (55) or other chemotherapy (inclusion criteria) (19), } \\
\text { other reasons (6) }\end{array}$ \\
\hline 74 & Study group & 45 & $\begin{array}{l}\text { Prefers to determine the therapy (22), prefers mistletoe (14), prefers no } \\
\text { injections (4), other (5) }\end{array}$ \\
\hline 29 & Willing to be randomized & & \\
\hline
\end{tabular}

insufficient compliance on the physicians' side (preference for other ongoing studies: i.e. recruitment for trials with conventional drugs if available; no equipoise in view of mistletoe treatment with Iscador; lack of methodological education for performing clinical trials) and on the patients' side [refusal of participation in trial, therapy preferences, in favor of Iscador; see also (23)]. However, trial participation generally has many hurdles and is particularly bad with patients having therapy preferences (24-29). The situation concerning recruitment and compliance in randomized studies is even more complicated in the context of complementary oncology compared to conventional oncology $(3,30-33)$.

Obviously, these difficulties were also encountered in completed studies. For instance, in a large trial in Germany during the eighties, the investigators had to revise the power calculation twice to reduce sample size, but still needed more than 9 years for patient recruitment (41). Another study needed considerably more time for completion than anticipated $(35,42)$. In addition, for both cases showing no significant effect of Iscador on tumor progression or survival, one can argue that they suffered from a false-negative bias $(3,4,6)$. Given these experiences, an empirical study was conducted to evaluate the willingness of patients to participate in a randomized clinical mistletoe trial (39). The results are shown in Table 2 and present a whole bundle of reasons why particular patients were not able to enter the trial. Among these, preference of mistletoe is the only mistletoe-specific reason for not participating. The refusal of trials in general as well as the wish to determine the therapy itself is prominent as well.

\section{Randomized Matched-pair Studies with Iscador}

The concept of randomized matched-pair studies is rather unusual in cancer research. The recruitment and randomization of patients for this kind of trial is executed pair-wise: From a successively filled pool of cancer patients not treated by any kind of mistletoe or therapy stimulating the immune system, pairs according to pre-specified prognostic factors are built and then randomized separately. Details of the randomization process (43) were executed according to pre-specified rules, in accordance with the suggestions of the CONSORT statement $(44,45)$.

\section{Randomization and Concealed Allocation}

Two slips of paper with names of the two matched partners were put into a hat by the primary investigator, and a masked assistant drew one of the slips. It was determined that the patient selected first was asked if he or she would be willing to ask the attending doctor for a complementary therapy using Iscador. Thus, intervention did not consist of giving a therapy with Iscador, but of making a suggestion for an Iscador therapy.

\section{Implementation}

The patient recruitment happened strictly according to the matching rules without interference from investigators. The random allocation result was implemented by the primary investigator non-involved in the random selection process.

\section{Consent}

The acceptance of participation in this kind of study is one-sided, i.e. only the patient being suggested a therapy with Iscador was informed about this process. The other patient as well as the respective attending physician was left uninformed. Thus, this is a special case of the single randomized consent design of Zelen (46-48). That research was planned and started in the early 70 s, where ethical committees did not yet exist; or there was 
Table 3. Randomized mistletoe studies with Iscador in matched-pair design; outcome is in all cases overall survival and psychosomatic self-regulation

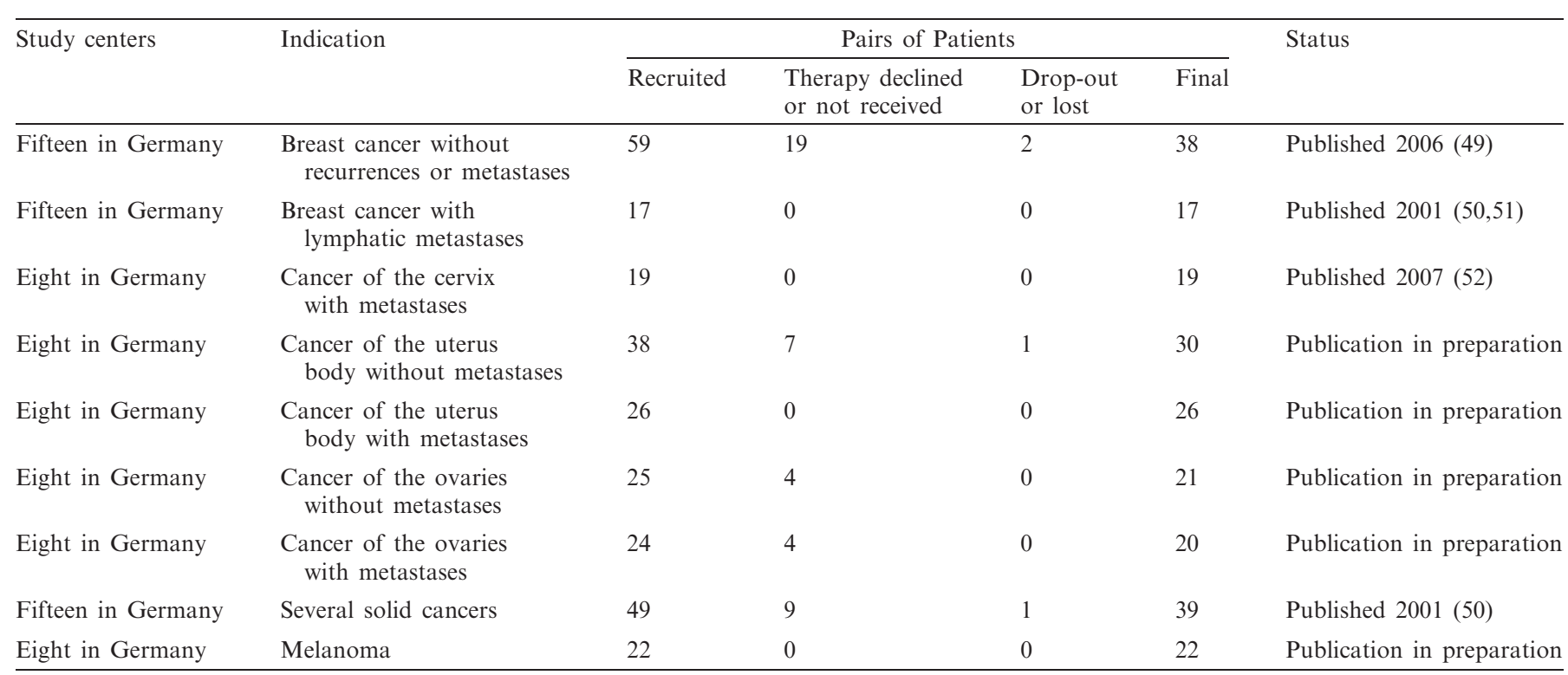

at least no mandatory requirement to have a study approved by them; however, one does not know their reaction on such a study proposal.

\section{Exclusion of Pairs}

If for any reason, a single patient had to be excluded, the whole matched-pair including this patient was excluded. The following criteria were applied to exclude patient pairs: (i) if the allocated suggestion for Iscador therapy has not been taken up either by the patient or the attending physician; (ii) if the control partner decided to start Iscador therapy or any other treatment modulating the immune system; (iii) if for one of the partners a certified non-tumor-related accident or suicide occurred; (iv) if after the matching process any patient refused to participate further for any reason, or if any partner dropped out for any other reason than death or if a patient could not be found any more in the follow-up process.

The statistical analysis of randomized clinical trials according to the principle of intention-to-treat $(53,54)$ has two aspects which need to be differentiated: first to preserve the statistical balance of the baseline factors in the two therapy groups and second to present an adequate picture of the real life situation, where noncompliance and drop-out occur and might be associated with the therapy and the outcome. However, a sufficiently complete picture of the whole situation is only given if the intention-to-treat analysis estimating the effect of assignment to therapy (use-effectiveness) is complemented with an estimated effect of actually administered therapy (method-effectiveness-not to be confused with a simple per-protocol-or as-treated analysis) $(55,56)$.
With respect to randomized matched-pair studies, the procedure of exclusion of pairs guarantees that randomization is not undermined by excluding patients. In other words, internal validity is not at issue since the structural comparability is preserved by pair-wise selection and exclusion. This covers the first aspect of an intention-to-treat analysis. However, by this exclusion process, not all randomized pairs are included in the analysis and hence there exists a kind of underreporting bias which does not interfere with the randomization but with the completeness of the analyzed data sets. A masking process was not applicable to the intervention of the randomized matched-pair studies, since it consisted not of a therapy as such but of a suggestion to perform a therapy with Iscador towards the randomly selected patient. In addition, neither the outcome assessors were masked nor the statisticians.

Nine studies of this kind have been executed (Table 3), four of which have been published $(49,50,52,57-59)$ and the rest await final analysis and publication. Most of these took a very long time to execute (more than 10 years) and there have been some patients who declined participation or did not receive Iscador therapy (Table 3).

\section{Concerns with Randomized Clinical Trials using Iscador}

According to the aforementioned results reported, recruitment for a conventional randomized controlled clinical trial (RCT) is difficult for several reasons: physician or patient preferences either in favor of or against mistletoe therapies, preferred co-interventions, patient and physician compliance and drop-outs. The long tradition of using mistletoe preparations in German speaking countries has the consequence that mistletoe in general and Iscador in particular is well known among 
cancer patients searching for complementary treatments. Thus, many informed patients explicitly want to use mistletoe extracts and therefore cannot be randomized.

Apart from this situation there are major general concerns using randomization and blinding in trials within complementary medicine (33). With respect to quality, blinding is nearly impossible in mistletoe studies: it was shown that at least in the long run most physicians and patients loose their blindness $(23,60)$. However, also in chemotherapy trials, blinding is rare (61). In addition, any kind of standardized therapy as used in conventional randomized clinical trials is not representative of a population using the mistletoe preparation Iscador as a cancer treatment.

Randomized matched-pair studies have the drawback of not being well accepted by conventional trial experts and methodologists because of the unusual design. And, they share some of the limitations of RCTs in general which make recruitment and implementation difficult: physician or patient preferences in favor of or against complementary treatments, patient preferences, refusal to trial in general, compliance, drop-outs, rigid inclusion and exclusion criteria. Furthermore, a fairly big pool of cancer patients is required to recruit enough matching pairs. Not all quality issues concerning randomized mistletoe research can be mentioned here. Some authors $(3,4,6)$ discuss other limits, particularly false-negative bias stemming from other kinds of biases.

\section{Prospective Non-randomized Controlled Iscador Studies}

Prospective non-randomized controlled studies are advantageous for including representative samples of patients and doing research on those receiving actual Iscador treatments, i.e. performing prospective data measurement. However, since they should consider all known possible prognostic factors and confounders, they tend to be expensive and, if the effect is not strong, unreliable due to selection bias $(62,63)$. Table 4 shows the nine controlled prospective non-randomized studies in parallel-group design with Iscador that were recently finished or are still ongoing. According to the quality assessments of some of these in $(4,6)$, they vary in quality. Compared to other types of cohort research $(21,22)$ few patients are included, but compared to the randomized trials, the situation is acceptable. Note that none of them was discontinued.

The main work in realizing cohort studies should focus on the design and implementation phase. That is the place where random as well as systematic errors (bias) can be minimized, particularly by specifying adequate inclusion and exclusion criteria, and where adequate measures against selection bias (the biggest challenge for non-randomized designs), performance bias, detection bias and attrition bias $(80,81)$ can be provided. In a systematic way, this has only been regarded in the four parallel-group studies: No. II, V, VI, VII and, to some extent, in study VIII with matched-pairs. The report on random and systematic error prevention is insufficient within the others (82), as is the statistical analysis.

\section{Prospective Non-randomized Matched-pair Studies with Iscador}

There are 16 prospective non-randomized matched-pairs studies with Iscador for different solid cancers, eleven published (50,52,57-59); the remaining still await analysis and publication.

Pair-wise matching is one of the strongest measures against selection bias in non-randomized cohort research. Within these, not only tumor-specific prognostic factors are considered, but also the year of diagnosis: for matching pairs, difference between the years of initial diagnosis is at most 3 years. This allows patient recruitment in pairs over a long period of time (and hence long periods of follow-up) without risking the danger of significantly different prognostic or therapeutic procedures due to medical progress. In other words: there is no danger of stage migration (83).

If for any reason a single patient was excluded, in any case the whole matched-pair including this patient was excluded. These pairs have neither been followed up nor used for other purposes in any other Iscador research. This process does not explicitly favor one of the two therapy groups. In most cases, the excluded patient pairs did not exceed $10 \%$ of those recruited. No study was prematurely terminated due to lack of patients. However, the recruitment period in most cases exceeded 10 years.

\section{Controlled Forward Longitudinal («retrolective») Cohorts using Iscador}

Controlled retrospective forward longitudinal («retrolective») cohort analyses (84) include systematic searches of patient archival data in clinical registries according to specific criteria of inclusion and exclusion, guided by a protocol that adheres to the principles of good epidemiological practice $(85,86)$. These are advantageous for being easy to implement for a long treatment period in a comparatively short data gathering period for a large sample. As such they give a picture of the real world effectiveness, since they do not require any additional selection process. The randomized selection of study centers from an available pool guarantees external validity. Their main disadvantage regards reliance on complete archival data, that is on a retrospective data collection (i.e. measurements and recordings of observations happened before study onset and for 
Table 4. Prospective controlled non-randomized mistletoe studies with Iscador in parallel-group design

\begin{tabular}{|c|c|c|c|c|c|}
\hline Study No. & Indication & Outcome parameter & $\begin{array}{l}\text { Patients } \\
\text { Iscador/Control }\end{array}$ & Status & Comments \\
\hline I & Cancer, different locations & IL-6 in blood serum & $99 / 28$ & Published 2000-04 (64-67) & $\begin{array}{l}\text { Evaluation of different patient } \\
\text { groups to measure the variations } \\
\text { of the IL-6 level in blood serum under } \\
\text { Iscador treatment compared to healthy controls }\end{array}$ \\
\hline II & $\begin{array}{l}\text { Advanced cancer of } \\
\text { different locations }\end{array}$ & $\begin{array}{l}\text { Socio-demographic and } \\
\text { medical characteristics }\end{array}$ & $221 / 280$ & Published 2002 (68) & Register study to evaluate patient characteristics \\
\hline III & Several gynecological cancers & QoL & $64 / 64$ & Published 2005 (69) & \\
\hline IV & Several gynecological cancers & Side effects of chemotherapy, QoL & $43 / 41$ & Published 2005 (70) & \\
\hline $\mathrm{V}$ & $\begin{array}{l}\text { Primary breast cancer } \\
\text { without metastases }\end{array}$ & $\begin{array}{l}\text { Immunological parameters, } \\
\text { QoL, safety }\end{array}$ & $33 / 33$ & Published 2005 (40) & $\begin{array}{l}\text { Feasibility study to prepare a randomized } \\
\text { mistletoe trial }\end{array}$ \\
\hline VI & Breast cancer & Granulocyte function, QoL & $53 / 52$ & Published 2004/05 (71-73) & $\begin{array}{l}\text { Modulation of immune suppression due to } \\
\text { operation with peri-operative i.v. infusion of } \\
\text { Iscador, GCP quality standards }\end{array}$ \\
\hline VII & Breast cancer & $\begin{array}{l}\text { Immunological parameters, QoL, } \\
\text { tolerability of chemotherapy, safety }\end{array}$ & $(50 / 50)$ & $\begin{array}{l}\text { Start of recruitment } 2004, \\
\text { preliminary publication }(74)\end{array}$ & $\begin{array}{l}\text { Modulation of immune suppression due to } \\
\text { chemotherapy with i.v. infusion of Iscador } \\
\text { before and after chemotherapy; slow recruitment; } \\
\text { GCP quality standards }\end{array}$ \\
\hline VIII & Breast cancer & Coping, QoL & $60 / 60$ & Published 2001-06 (75-78) & $\begin{array}{l}\text { Coping was measured using the Mental Adjustment } \\
\text { to Cancer Scale (MAC), Iscador and control } \\
\text { patients were matched }\end{array}$ \\
\hline IX & Ear, nose and throat & $\begin{array}{l}\text { Microcirculation, immunological } \\
\text { parameters }\end{array}$ & $10 / 10$ & Published 2005 (79) & $\begin{array}{l}\text { Small study to evaluate systemic and local } \\
\text { reactions at the injection site of Iscador treatment }\end{array}$ \\
\hline
\end{tabular}

(QoL, quality of life; GCP, good clinical practice) 
different reasons). Therefore they are subject to selection bias: measurements and recordings of all known prognostic factors, possible confounders, and all wanted and unwanted events cannot be assured. Four relevant studies are available, two of which are finished and published $(21,22)$ and the remaining two are still being analyzed and prepared for publication.

\section{Retrospective Controlled Cohort Studies with Iscador}

Three classical retrospective cohort studies have been performed since 1990 (87-89). They are easy to do and complement the overall picture concerning characteristics of the Iscador population.

\section{Reflections and Consequences}

\section{Quality}

There are avoidable problems of quality, such as transparency and completeness of reporting data. Other problems are more difficult to overcome; however, they are not specific to mistletoe and induce different kinds of biases $(3,4,6)$ : systematic differences in care provided apart from the mistletoe treatment (performance bias), dropouts, withdrawals and protocol deviations (attrition bias). If the outcome is survival or tumor progression, detection bias is not problematic. The situation for quality of life is more complicated necessitating the use of validated questionnaires.

\section{Duration of clinical phase}

Many mistletoe studies have a clinical phase of less than 12 months; one might argue, that this is insufficient to bring into action long-term effects of mistletoe therapy $(81,84,90)$. More research on long-term applications of Iscador is needed to evaluate effectiveness as well as safety.

\section{Designs}

If one wants to compare parallel groups, continue to randomize even if difficult. However, as shown earlier, recruitment may be the utmost problem for randomized trials with the mistletoe preparation Iscador. Before rejecting randomization, one should search for alternative designs for randomized trials [i.e. comprehensive cohort design (91-93), and (94-96)]. Thus randomized matchedpair studies might take a long time, depending on availability of patients, but they seem to be an alternative that requires evaluation. A survey within an academic center in the USA showed that for conventional physicians working in such an institution the attitude towards using complementary therapy methods may be strongly linked to the existence of randomized trials in favor of such a treatment (97). However, randomization does not solve all problems. If the number of recruited patients is small, they might not be representative. In addition, the use of randomization might severely undermine the representativeness (or the generalizability) of results, since patients who agree to randomization might be different from those who do not, especially in the context of complementary and alternative medicine, where strong preferences are more common $(36,68,98)$.

One of the most important points in this respect is to use different designs that complement each other $(99,100)$. This was the underlying reason for implementing randomized matched-pair studies together with non-randomized ones (50). Thus, well-designed nonrandomized research is not just an excuse for not being able to do randomized trials, but an important contribution to the overall clinical picture of Iscador therapy. If randomization is not possible or can only be done in small groups, one can use in addition prospective controlled non-randomized studies $(101,102)$ and adhere to high quality standards $(63,80,82)$. Under some circumstances, results of prospective controlled nonrandomized studies might be comparable to randomized for the same outcome and similar population characteristics (103-106). However, care is required to prevent overestimation $(62,63,82)$. If resources and time frames are limited, they can be complemented by retrospective controlled («retrolective») cohort studies using archival data and guided by a protocol (84-86) and by classical retrospective controlled cohort studies. If all this does not work, a look for other sorts of designs is essential (107). Even prospective one-arm studies can be useful, if designed and evaluated properly $(108,109)$.

\section{Centers}

It is essential to do research in countries or populations unaware of mistletoe, in general or Iscador in particular or where mistletoe is not readily available (as in Beograd or in the USA). The experience from Beograd (Table 1) shows: randomization is not a real problem; drop-outs are seldom, since patients are content having a chance to receive complementary therapy with Iscador; compliance is high, since patients follow closely the physician's instructions.

\section{Outcome}

Consider reduction of symptoms, side effects of conventional therapy (chemotherapy, radiotherapy) and quality of life in addition to survival and tumor behavior. 


\section{Preclinical Studies with Healthy Volunteers}

It was pointed out in (110) that there are also few in vivo controlled studies with healthy volunteers concerning immunomodulating effects of the mistletoe preparation Iscador or lectin extracts of mistletoe; however, the reasons are unknown. The trial in (110) complements the already existing four trials (111-117). Such research could be important for design of further clinical trials investigating the immunological effects of mistletoe preparations.

\section{Conclusion}

Randomized mistletoe research has been notoriously difficult to perform, especially in German speaking countries where mistletoe preparations are readily available outside of clinical trials. Patient and physician preference in favor of or against complementary therapy with mistletoe seem to be the most important factors limiting implementation of such trials with Iscador. This adds to the overall unwillingness of participation in trials for patients with serious diseases. Hence a well balanced mix of designs using different research methods and different outcomes is suggested, combined with research in countries, where mistletoe in general or Iscador in particular are unknown or unavailable.

\section{Acknowledgements}

Major improvements were possible through the comments of S. Baumgartner (Bern), R. Huber (Freiburg), M. Reif (Berlin), G. Kienle (Freiburg), P. Heusser (Bern) and by two anonymous reviewers.

\section{References}

1. Cassileth BR, Deng G. Complementary and alternative therapies for cancer. Oncologist 2004;9:80-9.

2. Moschen R, Kemmler G, Schweigkofler H, Holzner B, Dünser M, Richter $\mathrm{R}$, et al. Use of alternative/complementary therapy in breast cancer patients - a psychological perspective. Support Care Cancer 2001;9:267-74.

3. Kienle GS, Kiene H. Die Mistel in der Onkologie: Fakten und konzeptionelle Grundlagen. Stuttgart: Schattauer, 2004.

4. Kienle GS, Berrino R, Büssing A, Portalupi E, Rosenzweig S, Kiene H. Mistletoe in cancer: a systematic review on controlled clinical trials. Eur J Med Res 2003;8:109-19.

5. Kienle GS, Kiene H. Klinische Studien zur Misteltherapie der Krebserkrankung - Eine Übersicht. Erfahrungsheilkunde 2004;53:193-209.

6. Kienle GS, Kiene H. Complementary cancer therapy: a systematic review of prospective clinical trials on anthroposophic mistletoe extracts. Eur J Med Res 2007;12:1-17.

7. Ziegler R. Klinische Versuche und Beobachtungsstudien seit 1990 mit Mistelextrakten, insbesondere Iscador. Internes Dokument. Arlesheim: Vereins für Krebsforschung, 2006.

8. Urech K, Ziegler R. Documentation of Published Clinical Trials and Observational Studies with Iscador. Arlesheim: Verein für Krebs forschung (www.hiscia.ch/forschung/klink/dokumentation.htm); June 2006.
9. U.S. National Institutes of Health, National Cancer Institute: Mistletoe extracts (PDQ) (http://www.cancer.gov/cancerinfo/pdq/ $\mathrm{cam} / \mathrm{mistletoe).}$

10. Daems WF. Ita Wegman und das erste Mistelpräparat Iscar zur Krebsbehandlung. In: Leroi R (ed). Misteltherapie - Eine Antwort auf die Herausforderung Krebs: Die Pioniertat Rudolf Steiners und Ita Wegmans. Stuttgart: Freies Geistesleben, 1987, 35-44.

11. Büssing A. Biological and pharmacological properties of Viscum album L. In: Büssing A (ed). Mistletoe: The Genus Viscum. Amsterdam: Harwood Academic Publisher, 2000, 123-82.

12. Büssing A. Mistel (Viscum album) - anthroposophischer und phytotherapeutischer Ansatz. In: Münstedt K (ed). Ratgeber Unkonventionelle Methoden. Landsberg: Ecomed, 2003, 184-99.

13. Büssing A, Schietzel D, Schietzel M, Schink M, Stein GM. Keine Stimulation in-vitro-kultivierter Tumorzellen durch Mistellektin. Dtsch Z Onkol 2004;36:33-70.

14. Büssing A. Pharmakologische Wirkungen von Mistelextrakten. In: Fintelmann V (ed). Onkologie auf anthroposophischer Grundlage. Stuttgart: Mayer (1. Lieferung), 2002, Section 3.2.4.1.

15. Flückiger $H$, Baumgartner S. Auswirkungen des IscadorMaschinenprozesses auf Mistelextrakte in botanischen Untersuchungssystemen. Merkurstab 2003;56:114-21.

16. Matthiessen PF, Tröger W. Die Misteltherapie des Krebses. In: Wrba H (ed). Kombinierte Tumortherapie - Grundlagen, Möglichkeiten und Grenzen adjuvanter Methoden. Stuttgart: Hippokrates, 1995, 271-90.

17. Stein GM, Berg PA. Adverse effects during therapy with mistletoe extracts. In: Büssing A (ed). Mistletoe - The Genus Viscum. Amsterdam: Harwood Academic Publishers, 2000, 195-208.

18. Saller R, Kramer S, Iten F, Melzer J. Unerwünschte Wirkungen der Misteltherapie bei Tumorpatienten - Eine systematische Übersicht. In: Scheer R, Bauer R, Becker H, Fintelmann V, Kemper FH, Schilcher H (eds). Fortschritte in der Misteltherapie: Aktueller Stand der Forschung und klinische Anwendung. Essen: KVC Verlag, 2005, 367-403.

19. Saller R, Reichling J, Melzer J. Die Misteltherapie. Erwünschte und unerwünschte Wirkungen in der wissenschaftlichen Diskussion - Teil 1. PraxisMagazin 2005;21:6-14.

20. Saller R, Reichling J, Melzer J. Die Misteltherapie. Erwünschte und unerwünschte Wirkungen in der wissenschaftlichen Diskussion - Teil 2. PraxisMagazin 2005;22:6-17.

21. Bock PR, Friedel WE, Hanisch J, Karasmann M, Schneider B. Wirksamkeit und Sicherheit der komplementären Langzeitbehandlung mit einem standardisierten Extrakt aus Europäischer Mistel (Viscum album L.) zusätzlich zur konventionellen adjuvanten onkologischen Therapie bei primärem, nicht metastasiertem Mammakarzinom. Ergebnisse einer multizentrischen, komparativen, retrolektiven, epidemiologischen Kohortenstudie in Deutschland und der Schweiz. Arzneim/Drug Res 2004;54:456-66.

22. Augustin M, Bock PR, Hanisch J, Karasmann M, Schneider B. Safety and efficacy of the long-term adjuvant treatment of primary intermediate - to high-risk malignant melanoma (UICC/AJCC stage II and III) with a standardized fermented European mistletoe (Viscum album L.) extract: results from a multicenter, comparative, epidemiological cohort study in Germany and Switzerland. Arzneim/Drug Res 2005;55:38-49.

23. Rostock M, Huber R. Randomized and double blind studies demands and reality as demonstrated by two examples of mistletoe research. Forsch Komplementarmed 2004;11 (Suppl 1): $18-22$.

24. Prescott RJ, Gillespie WJ, Counsell CE, Grant AM, Ross S, Russell IT, et al. Factors that limit the quality, number and progress of randomised controlled trials. In: Black N, Brazier J, Fitzpatrick R, Reeves BC (eds). Health Services Research Methods: A Guide to Best Practice. London: BMJ Books, 1998, 86-97.

25. Prescott RJ, Counsell CE, Gillespie WJ, Grant AM, Russell IT, Kiauka $\mathrm{S}$, et al. Factors that limit the quality, number and progress of randomised controlled trials. Health Technol Assess 1999;3:1-134.

26. Ross S, Grant AM, Counsell CE, Gillespie WJ, Russell IT, Prescott RJ. Barriers to participation in randomised controlled trials: a systematic review. J Clin Epidemiol 1999;52:1143-56. 
27. Ellis PM. Attitudes towards and participation in randomised clinical trials in oncology: a review of the literature. Ann Oncol 2000;11:939-45.

28. King M, Nazareth I, Lampe F, Bower P, Chandler M, Morou M, et al. Conceptual framework and systematic review of the effects of participants' and professionals preferences in randomised controlled trials. Health Technol Assess 2005;9:1-186.

29. Robinson EJ, Kerr CEP, Stevens AJ, Lilford RJ, Braunholtz DA, Edwards SJL, et al. Lay public's understanding of equipoise and randomisation in randomised clinical trials. Health Technol Assess 2005;9:1-192.

30. Abel U. Spezielle Forschungsprobleme, Teil 1: Warum gibt es in der unkonventionellen Medizin so wenige aussagekräftige Studien? In: Bühring M, Kemper FH (eds). Naturheilverfahren und Unkonventionelle Medizinische Richungen, Sektion 01: Allgemeiner Teil. Vol. 01.08, Teil 1. Heidelberg: Springer, 1998, 1-8.

31. Abel U. Grundlagen der Biometrie. In: Beuth J (ed). Grundlagen der Komplementäronkologie. Stuttgart: Hippokrates, 2002, 45-62.

32. Hürny C, Heusser P, Bernhard J, Castiglione M, Cerny T. Verbessern nicht-konventionelle Zusatztherapien die Lebensqualität von Krebspatienten? - Eine methodenkritische Literaturübersicht. Schweiz Med Wochenschr 1994;124 (Suppl 62): 55-63.

33. Heusser P. Probleme von Studiendesigns mit Randomisation, Verblindung und Placebogabe. Forsch Komplementarmed 1999;6:89-102.

34. Salzer G, Danmayr E, Wutzlhofer F, Frey S. Adjuvante IscadorBehandlung operierter nicht kleinzelliger Bronchuskarzinome. Ergebnisse einer randomisierten Studie. Dtsch $Z$ Onkol 1991;23:93-98

35. Kleeberg U, Suciu S, Bröcker EB, Ruiter DJ, Chartier C, Liénard D, et al. Final results of the EORTC 18871/DKG 80-1 randomised phase III trial: rIFN-a2b versus rIFN-g versus ISCADOR $M$ versus observation after surgery in melanoma patients with either high-risk primary (thickness $>3 \mathrm{~mm}$ ) or regional lymph node metastasis. Europ J Cancer 2004;40:390-402.

36. Von Rohr E, Pampallona S, Van Wegberg B, Hürny C, Bernhard J, Heusser $\mathrm{P}$, et al. Experiences in the realisation of a research project on anthroposophical medicine in patients with advanced cancer. Schweiz Med Wochenschr 2000;130:1173-84.

37. Borrelli E. Valutazione della qualità di vita in pazienti affette da adenocarcinoma mammario sottoposte a terapia con Viscum album. Med Biol 1999,27-30.

38. Schink M, Tröger W, Dabidian A, Goyert A, Scheuerecker H, Meyer J, et al. Mistletoe extract reduces the surgical suppression of natural killer cell activity in cancer patients. A randomized phase III trial. Forsch Komplementarmed 2007;17:9-17.

39. Gerhard I, Abel U, Loewe-Mesch A, Huppmann S, Kuehn JJ. Problematik randomisierter Studien in der Komplementärmedizin dargestellt am Beispiel der Misteltherapie bei Patientinnen mit Mammakarzinom. Forsch Komplementarmed 2004;11:150-57.

40. Von Hagens C, Loewe-Mesch A, Kuehn JJ, Abel U, Gerhard I. Prospektive kontrollierte nicht randomisierte Machbarkeits-Studie $\mathrm{zu}$ einer postoperativen simultanen Mistel-/Chemotherapie bei Patientinnen mit Mammakarzinom - Ergebnisse zu Rekrutier- und Randomisierbarkeit, Immunparametern, Lebensqualität und Verträglichkeit. In: Scheer R, Bauer R, Becker H, Fintelmann V, Kemper FH, Schilcher H (eds). Fortschritte in der Misteltherapie: Aktueller Stand der Forschung und klinische Anwendung. Essen: KVC Verlag, 2005,567-78.

41. Dold U, Edler L, Mäurer CM, Müller-Wening D, Sakellariou B, Trendelenburg F, et al. Krebszusatztherapie beim fortgeschrittenen nicht-kleinzelligen Bronchialkarzinom - Multizentrische kontrollierte Studie zur Prüfung der Wirksamkeit von Iscador und Polyerga. Stuttgart: Thieme, 1991.

42. Eggermont AM, Kleeberg U, Ruiter DJ, Suciu S. European organization for research and treatment of cancer melanoma group trial experience with more than 2000 patients, evaluating adjuvant treatment with low or intermediate doses of interferon alpha-2b. In: Perry MC (ed). Educational Book, 37th Annual Meeting. Alexandria VA: American Society of Clinical Oncology, 2001,88-93.

43. Grossarth-Maticek R, Ziegler R. Randomisierte Kohortenstudien im Matched-Pair-Design zur Misteltherapie (Iscador) bei gynäkologischen Karzinomen. In: Scheer $\mathrm{R}$, Bauer $\mathrm{R}$, Becker $\mathrm{H}$,
Fintelmann V, Kemper FH, Schilcher H (eds). Fortschritte in der Misteltherapie: Aktueller Stand der Forschung und klinische Anwendung. Essen: KVC Verlag, 2005, 611-23.

44. Moher D, Schulz KF, Altman DG. The CONSORT statement: revised recommendations for improving the quality of reports of parallel-group randomized trials. $J$ Am Med Assoc 2001;285:1987-91.

45. Altman DG, Schulz KF, Moher D, Egger M, Davidoff F, Elbourne D, et al. The revised CONSORT statement for reporting randomized trials: explanation and elaboration. Ann Intern Med 2001;134:663-94.

46. Zelen M. A new design for randomized clinical trials. $N$ Engl J Med 1979;300:1242-45.

47. Zelen M. Randomized consent designs for clinical trials: an update. Stat Med 1990;9:645-56.

48. Altman DG, Whitehead J, Parmar MK, Stenning SP, Fayers PM, Machin DM. Randomised consent design in cancer clinical trials. Eur J Cancer 1995;31A:1934-44.

49. Grossarth-Maticek R, Ziegler R. Prospective controlled cohort studies on long-term therapy of breast cancer patients with a mistletoe preparation (Iscador). Forsch Komplementarmed 2006;13:285-92.

50. Grossarth-Maticek R, Kiene H, Baumgartner S, Ziegler R. Use of Iscador, an extract of European mistletoe (Viscum album), in cancer treatment: prospective nonrandomized and randomized matched-pairs studies nested within a cohort study. Altern Ther Health Med 2001;7:57-78.

51. Grossarth-Maticek R, Ziegler R. Randomised and non-randomised prospective controlled cohort studies in matched pair design for the long-term therapy of breast cancer patients with a mistletoe preparation (Iscador): a re-analysis. Europ $J$ Med Res 2006;11:485-95.

52. Grossarth-Maticek R, Ziegler R. Prospective controlled cohort studies on long-term therapy of cervical cancer patients with a mistletoe preparation (Iscador). Forsch Komplementarmed 2007;14:140-47.

53. Montori VM, Guyatt GH. Intention-to-treat principle. Can Med Assoc J 2001;165:1339-41.

54. Windeler J. Das Intention-to-treat-Prinzip in klinischen Arzneimittelprüfungen. Arzneimitteltherapie 1993;11:103-11.

55. Sheiner LB, Rubin DB. Intention-to-treat analysis and the goals of clinical trials. Clin Pharmacol Ther 1995;57:6-15.

56. Sheiner LB. Is intent-to-treat analysis always (ever) enough? $\mathrm{Br} \mathrm{J}$ Clin Pharmacol 2002;54:203-11.

57. Grossarth-Maticek R, Kiene H, Baumgartner S, Ziegler R. Addendum to Iscador article. Altern Ther Health Med 2001;7:26.

58. Grossarth-Maticek R, Kiene H, Baumgartner S, Ziegler R. Verlängerung der Überlebenszeit von Krebspatienten unter Misteltherapie (Iscador) - Ergebnisse einer epidemiologischen Langzeitstudie. Schweiz Z Ganzheitsmed 2001;13:217-25.

59. Grossarth-Maticek R, Kiene H, Baumgartner S, Ziegler R. Synergieeffekte von Selbstregulation und Misteltherapie (Iscador) auf die Überlebenszeit bei Krebspatienten - Ergebnisse einer epidemiologischen Langzeitstudie, Teil II. Schweiz Z Ganzheitsmed 2004; 16:81-9.

60. Auerbach L, Dostal V, Václavik-Fleck I, Kubista E, Rosenberger A, Rieger S, et al. Signifikant höherer Anteil aktivierter NK-Zellen durch additive Misteltherapie bei chemotherapierten Mamma-Ca-Patientinnen in einer prospektivrandomisierten doppelblinden Studie. In: Scheer R, Bauer R, Becker H, Fintelmann V, Kemper FH, Schilcher H (eds). Fortschritte in der Misteltherapie: Aktueller Stand der Forschung und klinische Anwendung. Essen: KVC, 2005, 543-54.

61. Nygren P, Glimelius B. The Swedish council on technology assessment in health care (SBU) report on cancer chemotherapy project objectives, the working process, key definitions and general aspects of cancer trial methodology and interpretation. Acta Oncol 2001;40:155-65.

62. Deeks JJ, Dinnes J, D'Amico R, Sowden A, Sakarovitch C, Song F, et al. Evaluating non-randomised intervention studies. Health Technol Assess 2003;7:1-173.

63. Reeves BC. Reasons for caution when evaluating health care interventions using non-randomised study designs. Forsch Komplementarmed 2004;11 (Suppl 1): 40-5.

64. Kovacs E. Serum levels of IL-12 and the production of IFN-gamma, IL-2 and IL-4 by peripheral blood mononuclear 
cells (PBMC) in cancer patients treated with Viscum album extract. Biomed Pharmacother 2000;54:305-10.

65. Kovacs E. Viscum album und Interleukin-6 - Was ist daran? In: Scheer R, Bauer R, Becker H, Berg PA, Fintelmann V (eds). Die Mistel in der Tumortherapie Grundlagenforschung und Klinik. Essen: KVC Verlag, 2001, 315-25.

66. Kovacs E, Kuehn JJ. Measurements of IL-6, soluble IL-6 receptor and soluble gp130 in sera of B-cell lymphoma patients. Does VISCUM ALBUM treatment affect these parameters? Biomed Pharmacother 2002;56:152-58.

67. Kovacs E. Effects of Viscum album extract therapy in patients with cancer: relation with interleukin-6, soluble interleukin-6 receptor, and soluble gp130. J Altern Complement Med 2004:10:241-46.

68. Pampallona S, Von Rohr E, Van Wegberg B, Bernhard J, Helwig S, Heusser P, et al. Socio-demographic and medical characteristics of advanced cancer patients using conventional or complementary medicine. Onkologie 2002;25:165-170.

69. Toelg M, Reiss B, Antonu H. Chemotherapie mit begleitender Misteltherapie - Prospektive, nicht randomisierte, kontrollierte, offene Studie (AWB) zur Lebensqualität. CO'MED 2005;11:18-22.

70. Toelg M, Antonu H, Reiss B, Ramos MH. Lebensqualität von Tumorpatientinnen unter begleitender Misteltherapie - Ergebnisse einer prospektiven, nicht randomisierten, kontrollierten, offenen Studie (AWB) mit Iscador M. Schweiz Z Ganzheitsmed 2005;17:294-99.

71. Büssing A, Bischof M, Hatzmann W, Bartzsch F, Soto-Vera D, Fronk E-M, et al. Beeinflussung der Granulozytenfunktion durch einmalige perioperative Mistelextrakt-Infusion. Dtsch Z Onkol 2004;36:148-53.

72. Büssing A, Bischof M, Hatzmann W, Bartzsch F, Soto Vera D, Fronk E-M, et al. Beeinflussung der Granulozytenfunktion durch eine perioperative Infusion eines fermentierten Mistelextraktes. In: Scheer R, Bauer R, Becker H, Fintelmann V, Kemper FH, Schilcher H (eds). Fortschritte in der Misteltherapie: Aktueller Stand der Forschung und klinische Anwendung. Essen: KVC Verlag, 2005, 555-66.

73. Büssing A, Bischof M, Hatzmann W, Bartsch F, Soto Vera D, Fronk E-M, et al. Prevention of surgery-induced suppression of granulocyte function by intravenous application of a fermented extract from Viscum album L. in breast cancer patients. Anticancer Res 2005;25:4753-58.

74. Büssing A. Immune modulation using mistletoe (Viscum album L.) extracts Iscador. Arzneim/Drug Res 2006;56:508-15.

75. Carlsson M, Arman M, Backman M, Hamrin E. Perceived quality of life and coping for Swedish women with breast cancer who choose complementary medicine. Cancer Nurs 2001;24:395-401.

76. Carlsson M, Arman M, Backman M, Flatters U, Hatschek T, Hamrin E. Evaluation of quality of life/life satisfaction in women with breast cancer in complementary and conventional care. Acta Oncol 2004;43:27-34.

77. Carlsson M, Arman M, Backman M, Hamrin E. Coping in women with breast cancer in complementary and conventional care over 5 years measured by the mental adjustment to cancer scale. $J$ Altern Complement Med 2005;11:441-47.

78. Carlsson M, Arman M, Backman M, Flatters U, Hatschek T, Hamrin E. A five-year follow-up of quality of life in women with breast cancer in anthroposophic and conventional care. Evid Based Complement Alternat Med 2006;3:523-31.

79. Klopp R, Schmidt W, Werner E, Werner M, Niemer W, Beuth J. Influence of complementary Viscum album (Iscador) administration on microcirculation and immune system of ear, nose and throat carcinoma patients treated with radiation and chemotherapy. Anticancer Res 2005;25:601-10.

80. Ziegler R. Elements of therapeutic research structure. Forsch Komplementarmed 2004;11 (Suppl 1): 5-12.

81. Ziegler R. Möglichkeiten und Grenzen klinischer Studien mit Iscador. Mistilteinn 2004;5:44-73.

82. Reeves BC, Gaus W. Guidelines for reporting non-randomised studies. Forsch Komplementarmed 2004;11 (Suppl 1): 46-52.

83. Feinstein AR, Sosin DM, Wells CK. The Will Rogers phenomenon: stage migration and new diagnostic techniques as a source of misleading statistics for survival in cancer. $N$ Engl $J$ Med 1985;312:1604-08.
84. Ziegler R. Neue Studien zum Mammakarzinom und zum malignen Melanom mit dem Mistelpräparat Iscador. In: Streit E, Rist L (eds). Ethik und Wissenschaft in der anthroposophischen Medizin. Bern: Peter Lang, 2006, 95-114.

85. Bock PR, Friedel WE, Hanisch J, Karasmann M, Schneider B. Retrolective, comparative, epidemiological cohort study with parallel groups design for evaluation of efficacy and safety of drugs with "well established use" - experience with the long-term treatment using the European mistletoe extract (Viscum album L.) in addition to conventional oncologic therapy in primary, non-metastatic breast carcinoma. Forsch Komplementarmed 2004;11 (Suppl 1): 23-29.

86. Schneider B. Beobachtungsstudien zum Nachweis der Wirksamkeit von Arzneimitteln. Dtsch $Z$ integrative Onkol 2004;2:22-7.

87. Hellan J, Danmayr E, Hellan M. Stellenwert der Komplementärmedizin in der Behandlung onkologischer Patienten - dargestellt anhand des kolo-rektalen Karzinoms. Dtsch Z Onkol 1995;27:85-94.

88. Schaefermeyer G, Schaefermeyer H. Treatment of pancreatic cancer with Viscum album (Iscador): a retrospective study of 292 patients 1986-1996. Complement Ther Med 1998;6:172-77.

89. Stumpf C, Rieger S, Schietzel M. Retrospektive Untersuchung zur Therapie mit Mistelextrakten bei Mammakarzinom. Dtsch Z Onkol 2005;37:106-13.

90. Ziegler R. Neuere klinische Studien mit Iscador zum Mammakarzinom und malignen Melanom. Mistilteinn 2004:5:74-99.

91. Schumacher M, Davis CE. Combining randomized and nonrandomized patients in the statistical analysis of clinical trials. Recent Results Cancer Res 1988;111:130-37.

92. Schmoor C, Olschewski M, Schuhmacher M. Randomized and non-randomized patients in clinical trials: experiences with comprehensive cohort studies. Stat Med 1996;15:263-71.

93. Olschewski M, Schumacher M, Davis K. Analysis of randomized and non-randomized patients in clinical trials using the comprehensive cohort follow-up study design. Control Clin Trials 1992;13:226-39.

94. Chow SC, Liu JP. Design and Analysis of Clinical Trials: Concepts and Methodologies. New York: John Wiley \& Sons, 1998.

95. Piantadosi S. Clinical Trials: A Methodologic Perspective. New York: John Wiley \& Sons, 1997.

96. Schumacher M, Schulgen G. Methodik klinischer Studien. BerlinHeidelberg: Springer, 2002.

97. Wahner-Roedler DL, Vincent A, Elkin PL, Loehrer LL, Cha SS, Bauer BA. Physicians' attitudes toward complementary and alternative medicine and their knowledge of specific therapies: a survey at an academic medical center. Evid Based Complement Alternat Med 2006;3:495-501.

98. Von Rohr E, Pampallona S, Van Wegberg B, Cerny T, Hürny C, Bernhard $\mathrm{J}$, et al. Attitudes and beliefs towards disease and treatment in patients with advanced cancer using anthroposophiscal medicine. Onkologie 2000;23:558-63.

99. Walach H, Falkenberg T, Fønnebø V, Lewith G, Jonas WB. Circular instead of hierarchical: methodological principles for the evaluation of complex interventions. BMC Med Res Methodol 2006;6 (Suppl 29): 1-9.

100. Heusser P. Kriterien zur Beurteilung des Nutzens von komplementärmedizinischen Methoden. Forsch Komplementarmed 2001;8:14-23.

101. Rosenbaum PR. Observational Studies, 2nd edn. New York: Springer, 2002.

102. Hulley SB, Cummings SR, Browner WS, Grady D, Hearst N, Newman TB. Designing Clinical Research. Philadelphia: Lippincott Williams \& Wilkins, 2001.

103. Benson K, Hartz AJ. A comparison of observational studies and randomized, controlled trials. $N$ Engl J Med 2000;342:1878-86.

104. Concato J, Shah N, Horwitz RI. Randomized, controlled trials, observational studies, and the hierarchy of research designs. $N$ Engl J Med 2000;342:1887-92.

105. MacLehose RR, Reeves BC, Harvey IM, Sheldon TA, Russell IT, Black AM. A systematic review of comparisons of effect sizes derived from randomised and non-randomised studies. Health Technol Assess 2000;4:1-145. 
106. Reeves BC, MacLehose RR, Harvey IM, Sheldon TA, Russell IT, Black AM. Comparison of effect sizes derived from randomised and non-randomised studies. In: Black N, Brazier J, Fitzpatrick R, Reeves BC (eds). Health Services Research Methods: A Guide to Best Practice. London: BMJ Books, 1998, 73-85.

107. Shadish WR, Cook TD, Campbell DT. Experimental and Quasi-Experimental Designs for Generalized Causal Inference. Boston: Houghton Mifflin, 2002.

108. Heusser P, Berger Braun S, Ziegler R, Bertschy M, Helwig S, Van Wegberg B, Cerny T. Palliative in-patient cancer treatment in an anthroposophic hospital: I. Treatment patterns and compliance with anthroposophic medicine. Forsch Komplementarmed 2006;13:94-100.

109. Heusser P, Berger Braun S, Bertschy M, Burkhard R, Ziegler R, Helwig S, et al. Palliative in-patient cancer treatment in an anthroposophic hospital: II. Quality of life during and after stationary treatment, and subjective treatment benefits. Forsch Komplementarmed 2006;13:156-66.

110. Hajto T, Hostanska K, Berki T, Palinkas L, Boldizsar F, Nemeth P. Oncopharmacological perspectives of a plant lectin (Viscum album Agglutinin-I): overview of recent results from in vitro experiments and in vivo animal models, and their possible relevance for clinical applications. Evid Based Complement Alternat Med 2005;2:59-67.

111. Klopp R. Immunmodulation mit Iscador. Schweiz Z GanzheitsMed 2001:13:290-91.

112. Wispler MJ, Kappler M, Soto Vera D, Reif M, Schnelle M, Zänker KS. Prospektive, randomisierte, kontrollierte Studie zur Aktivierung des Homings und des allgemeinen Aktivitätsniveaus von T-Lymphozyten durch subkutane
Mistelextrakt-Injektionen bei gesunden männlichen Probanden. In: Scheer R, Bauer R, Becker H, Fintelmann V, Kemper FH, Schilcher $\mathrm{H}$ (eds). Fortschritte in der Misteltherapie: Aktueller Stand der Forschung und klinische Anwendung. Essen: KVC Verlag, 2005, 513-25.

113. Huber R, Klein R, Berg PA, Lüdtke R, Werner M. Effects of a lectin and viscotoxin rich mistletoe preparation on clinical and hematological parameters: a placebo controlled evaluation in healthy subjects. $J$ Altern Complement Med 2002;8:857-66.

114. Klein R, Classen K, Berg PA, Lüdtke R, Werner M, Huber R. In vivo- induction of antibodies to mistletoe lectin-1 and viscotoxin by exposure to aqueous mistletoe extracts: a randomised double- blinded placebo controlled phase I study in healthy individuals. Eur J Med Res 2002;7:1-9.

115. Huber R, Classen K, Werner M, Klein R. In-vitro-Immunreaktion gegen Lektin-reiche und Viscotoxin-reiche Mistel (Viscum album L.)-Extrakte Iscador nach Verabreichung an gesunde Probanden Eine randomisierte doppelblinde Plazebo-kontrollierte Studie. Arzneim/Drug Res 2006;56:447-56.

116. Huber R, Rostock M, Goedl R, Lüdtke R, Urech K, Buck S, et al. Mistletoe treatment induces GM-CSF- and IL-5 production by PBMC and increases blood granulocyte- and eosinophil counts: a placebo-controlled randomized study in healthy subjects. Eur J Med Res 2005;10:411-18.

117. Huber R, Rostock M, Goedl R, Lüdtke R, Urech K, Klein R. Immunologic effects of mistletoe lectins: a placebo-controlled study in healthy subjects. $J$ Soc Integr Oncol 2006;4:3-7.

Received February 16, 2007; accepted June 7, 2007 


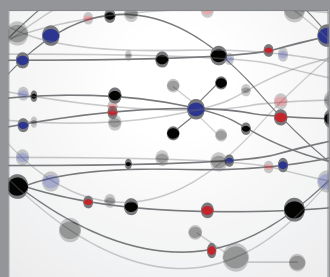

The Scientific World Journal
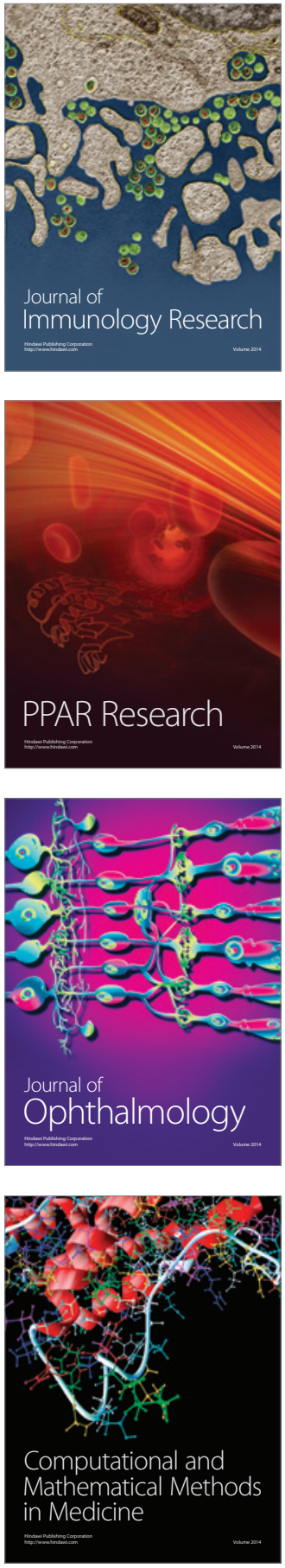

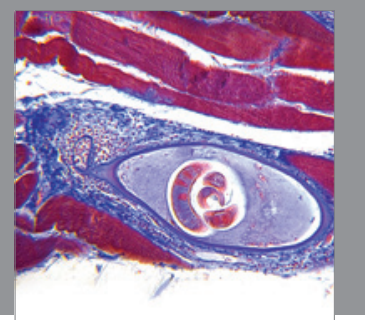

Gastroenterology

Research and Practice
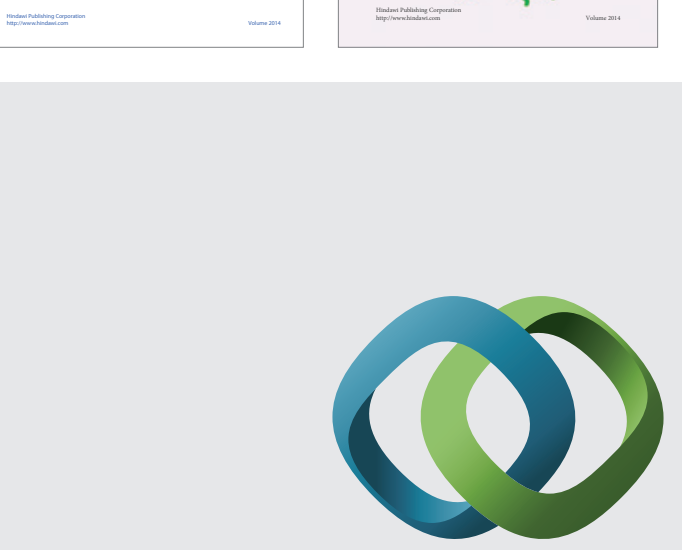

\section{Hindawi}

Submit your manuscripts at

http://www.hindawi.com
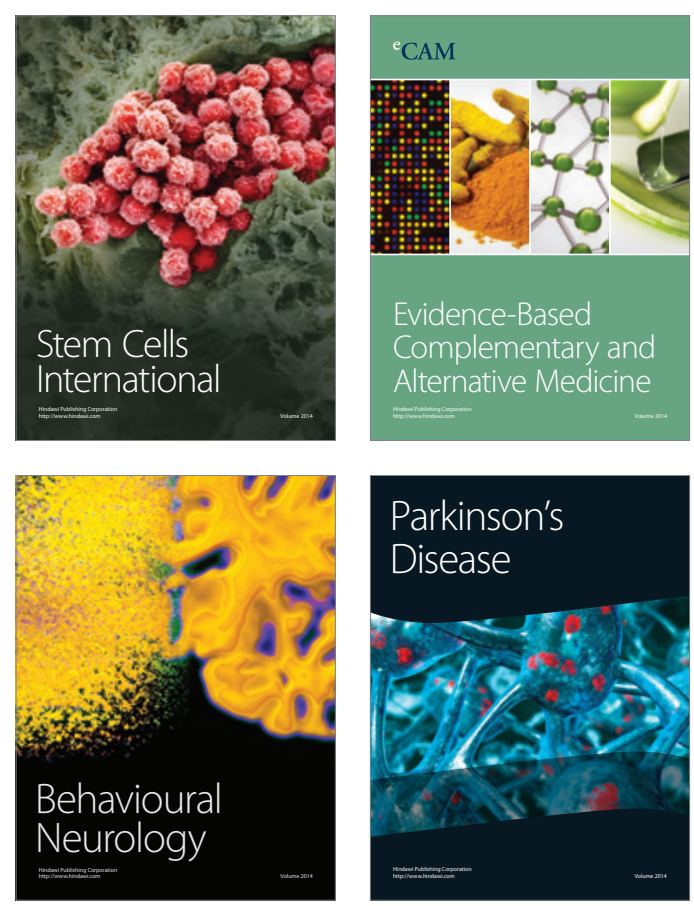

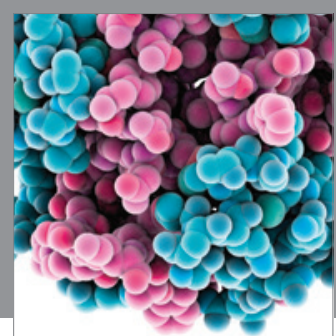

Journal of
Diabetes Research

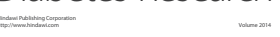

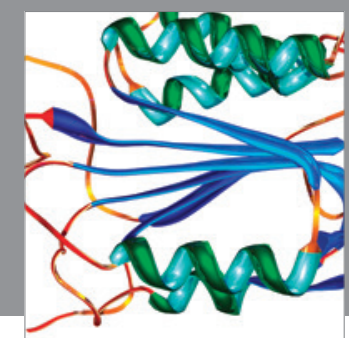

Disease Markers
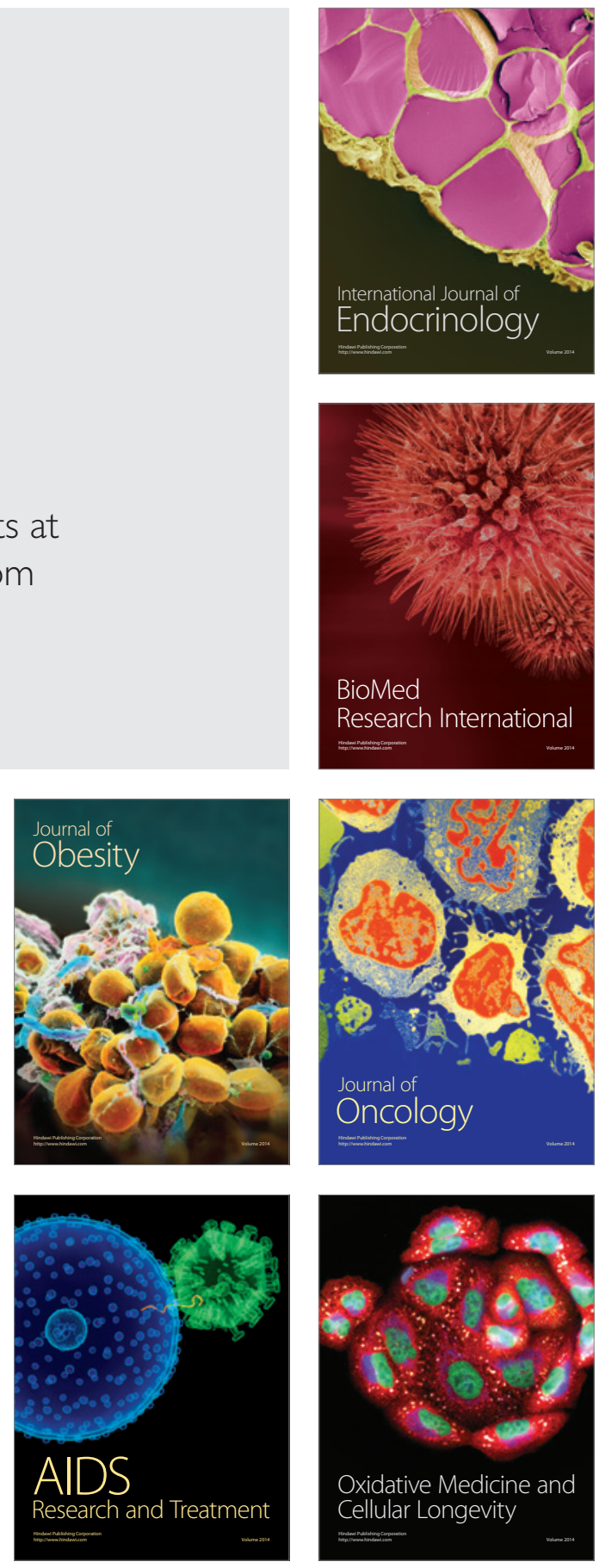